\title{
Assessment of the traditional goat production systems in rural areas of the Nile Delta in Egypt
}

\author{
S. Abd-Allah*, M. I. Mohamed, M. M. Shoukry, Fatma M. Salman and H. H. Abd- El Rahman
}

\begin{abstract}
Background: Description of goat populations in Egypt is necessary for providing information on common goat types and their characteristics and may be essential for the pointing and accomplishment of any intervention strategies willing to preserve and manage goat genetical resources at the rural districts based level. The aim of this study, therefore, was to characterize traditional goat production systems in some villages of the Nile Delta in Egypt. We conducted structured questionnaire interviews and participatory assessments for five villages of Menoufia governorate involved in farming livestock and in animal health. Elementary data were collected using an interview scheduled. Data composed on socio-demographic characteristics of the farmers were analyzed using frequency counts and percentages.
\end{abstract}

Results: Recorded data indicated that there were different contributions of livestock species to household livelihood. The results recorded that most of the farmers were male in all villages. The livestock owned comprised of buffalo, local cattle, crossbred cattle, sheep, donkey, chicken, rabbits, and ducks. There was general agreement among the respondents that crop farming, livestock, and goats were important for livelihoods, where it recorded the highest percentage $(79,77$, and $76 \%)$, respectively. Twin kids of goats were the majority type of births (62\%), also does with multiple births were more popular and preferred (98\%) for farmers compared to single births (2\%). With regard to production categories, the number of goat kids born emerged as the highly important categories for keeping goats in the opinion of all farmers (70\%). Most of farmers indicated that crop farming and livestock keeping as the main system in their livelihoods (69\%). Irrespective of the village, a large percentage of farmers (89\%) indicated that cash income from the sale of goats was one of the important reasons for keeping the goat. Daily milk yields were not estimated by farmers and not taken into account. Most of the farmers (90\%) indicated that lack of access to improved goats is the main constraint specified. Parasites (both internal and external) and pneumonia were recorded as important disease categories, but internal parasites were given high importance by all farmers (31\%). Goats did not sell through any formal market channel in villages under study and goat meat is not found in any butchery or shelves of the villages' supermarkets.

Conclusions: From these results, we concluded that this study can provide us with a baseline survey of which the information can be used in future projects to develop the traditional goat production systems in rural areas of the Nile Delta in Egypt.

Keywords: Goats, Production systems, Survey, Questionnaire, Village, Menoufia, Egypt

\footnotetext{
* Correspondence: Sablogical2007@yahoo.com

Animal Production Department, National Research Centre, 33 El Bohouth St., Dokki, Cairo 12622, Egypt
} 


\section{Introduction}

The Arab Republic of Egypt (ARE) has a surface of 1,001, $449 \mathrm{~km}^{2}$, but only $50,000 \mathrm{~km}^{2}$ are habitable and correspond basically to the Nile river irrigated lands. Geographically and in a simplified way, the country is divided into two regions, known as Upper (Nile Valley) and Lower Egypt (Nile Delta). The Delta region is the fourth of the seven regions of Egypt. It includes the governorates of Gharbia, Dakahlia, Damietta, Kafr El-Sheikh, and Menoufia with a total area of $12,357.4 \mathrm{~km}^{2}$ (2.94 million feddans) representing about $1.22 \%$ of the total area of the Republic. It also has about 19,145,755 people according to 2015 estimates. In 2018, the total population of Menoufia was 4, 366,000 people, with a rural population representing $78.37 \%$ of the total governorate population (CAPMAS 2018). A rural community is a part of land outside the densely populated urban areas in a city or town. The rural communities are traditionally areas not included in the urban definition and are usually large, open areas with little people and few houses, compared to urban areas which have larger populations. In rural communities, people live further away from one another and the distances between their homes and businesses are greater (Safeopedia 2019). Livestock and crop farming are the major source of food production and income in rural areas (Kunene and Fossey 2006). Goats are also kept as a source of cash, insurance against poverty, and also for other purposes (Sibisi 1981). Goats often require less start-up capital and can easily be raised even by poor people with limited land resources. Many development organizations in rural districts encourage rearing of goats to improve the income and nutrition status of the resource-poor people (Randolph et al. 2007). From our point of view and according to my previous studies, goats are consider as the most important small ruminants, which can be best exploited to escape from the poverty trap, especially for farmers in rural areas because they provide tangible benefits such as cash income from sales, meat, manure, skins, and fiber (Abd-Allah 2014; Abd-Allah et al. 2015, 2016). The aim of this study was to provide a great deal of information on traditional goat production systems in rural areas through assessing reproductive performance, reasons for keeping goats, and main constraints of goats under rural management condition in the Nile Delta in Egypt.

\section{Materials and methods}

\section{Location of the study area}

Menoufia governorate lies in the South of the middle Delta region between Damietta (Dumyat) and Rosetta (Rashid) branches. It is bordered by Gharbia in the North, by Giza in the South West, by Qaliobia in the South East, and by El-Beheira governorate in the West. This area is located at $30.52^{\circ} \mathrm{N}$ and $30.99^{\circ} \mathrm{E}$, it takes the triangle shape, where its head is the South, and its base is the North. The area experiences relatively moderate temperatures, with highs usually not surpassing $31{ }^{\circ} \mathrm{C}$ $\left(88^{\circ} \mathrm{F}\right)$ in the summer. Receiving rainfall with an annual average between 100 and $200 \mathrm{~mm}$ falls on the Delta area during a year and most of this rainfall in the winter season. The summer season begins in June and the hottest temperatures are in July and August, with a maximum average of $34{ }^{\circ} \mathrm{C}\left(93{ }^{\circ} \mathrm{F}\right)$. Winter temperatures are normally in the range of $9{ }^{\circ} \mathrm{C}\left(48{ }^{\circ} \mathrm{F}\right)$ at nights to $19{ }^{\circ} \mathrm{C}$ $\left(66^{\circ} \mathrm{F}\right)$ in the daytime. Agriculture is the main activity in the governorate due to its fertile soil. Total cultivated area covers 378.43 thousand feddans. Ashmoun is considered one of the poorer rural districts and it is located in the southern part of the Menoufia. It is the largest district in Menoufia, and a large number of animals and production is concentrated here. Ashmoun shares borders with the districts El-Bagour, Menouf, and Sadat in the North, Qaliobia governorate in the East and South, Giza governorate in the West.

For this study, five villages were purposively selected from Ashmoun district, based on the following criteria: village farmers were able to provide information related to this study, every village contained more than 100 households and ease of access. Although ideally all five villages would have been included in the study, resources for this study were limited and insufficient. The majority of the people depend on smallholder subsistence farming. The majority of the farmers in the villages are poor and typically own small plots of land of fewer than two feddans. Traditionally, the agricultural practices of the farmers in these villages consist of planting field crops, vegetables, and raising livestock.

\section{Participants}

We have chosen farmers randomly with the help of the butchers and agricultural extension workers. In this way, invitations were issued to 100 participants orally and it was assumed that some invitees would not respond. Fortunately, this did not happen; while in other cases, residents of the village that had not been invited showed interest and joined a farmer group. All participants were asked to answer the questionnaire in accordance with their own experience and knowledge. Any points requiring clarification or explanation were dealt with during the time when respondents gave their answers to the questions. The nature of the questionnaire was not disclosed and was conducted in an open dialog with them and was recorded completely through the mobile phone without their knowledge to ensure the transparency and credibility of the talk. Individual farmers were interviewed separately or in groups. Therefore, different views are likely to play a role in responses given. However, any group's responses to questions were very unlikely to have been influenced by other groups. 


\section{Data collection}

This study was conducted during a 2-year questionnaire (from April 2016 to August 2018). Surveys were conducted among livestock farmers (the word farmers refer to land farmers or owners) in rural areas of the Nile Delta in Egypt. For all surveys, questionnaires were developed in English and later translated to Arabic. We used simple language, which is the prevalent language suitable for farmers' levels. Questionnaires were pilot tested and changes were made where things were unclear and could be misunderstood by survey participants. In addition to questionnaires, we were interested to register most of the farmer observations in checklists. Also, we were taking photos and voice recordings by phone as often as possible. The collected data were covering the sociodemographic characteristics of farmers including the age of the farmer, sex of the head of the family, marital status, level of education of the farmer, land ownership, and sources of income. Specific and detailed information about the role of goats, production system, management problems and potentials, and how to overcome these problems were the main topics of the interviews. Information concerning problems and potential for goat production in each village were collected using participatory diagnosis. Data obtained included broad agricultural production systems, the importance of goats to the villagers, reasons of keeping goat, advantages and disadvantages of goat production, reproductive performances, and farmers' experience to overcome the problems associated with the keeping of goats. The findings of the questionnaires, after analysis, were used as the basis of the results recorded and discussed in this study.

\section{Statistical analysis}

All responses from all villages were collected, checked, and filed in groups according to the categories of respondents. Data collected from the respondents were analyzed using descriptive statistics, frequencies counts, and percentages by using the statistical package (SPSS 2008).

\section{Results}

\section{General information of farmers in rural areas of the Nile Delta in Egypt}

Table 1 gives the basic socio-economic and demographic characteristics of the rural areas of the Nile Delta in Egypt. The mean age of the farmers ranged from 20 to $>60$ years. The respondents were mainly in their active age of between 20 and 50 years old. The mean age of the farmers (23\%) were between the ages 31 and 40, 22\% were between the ages 41 and 50, and $20 \%$ were less than 30 years old; only $10 \%$ of the farmers were above 60 years old. Majority of the farmers interviewed were married (79\%) (Table 1). The assessment of their education level indicated that $14 \%$ of farmers did not go to school and $67 \%$ of farmers have acquired primary and secondary education while $19 \%$ of farmers have a university qualification. The majority of the farmers pointed out that their land was being leased (40\%) while others' land source is through the family $(28 \%)$ and owner (32\%)..

The main source of income was work (30\%) and a combination of sales and work (15\%) (Table 1). The types of work reported were the construction work in the village of Shanway, cultivation of the ornamental trees in the village of Kafr El-Hama, the manufacture of hand-made carpets in the village of Sakyet Abu Sha'ra, and others (agricultural works) in both the villages of Samalay and Kafr El-Pharaonia. A pension was the sole income of $14 \%$ of the farmers.

\section{Importance of livestock to farmers in rural areas of the Nile Delta in Egypt}

There was general agreement among the respondents that crop farming, livestock, and specially goats were important for livelihoods, where it recorded the highest percentages 79,77 , and $76 \%$, respectively. It also has the highest percentage for the different villages under study. The livestock types kept in the villages were buffalo, local cattle, crossbred cattle, sheep, goats, donkeys, chickens, ducks, and rabbits (Table 2). Majority of the farmers were not interested in Buffalo. Sixty-eight percent of the farmers were interested in sheep, $76 \%$ were interested in goats, while $47 \%$ were interested in buffalo. The number of farmers interested ranged between 8 and 13 farmers, while the common range in local cattle was between 6 and 12 .

The results presented in Fig. 1 indicated that goats were the highest importance for the total livestock in all villages, followed by other livestock (chickens, ducks, and rabbits); however, the donkeys were the lowest (22\%).

Productive and reproductive traits of Baladi goats in rural areas of the Nile Delta in Egypt

Reports of the survey study showed that the common flock size of goats reared by farmer households was a 13 head. On average, the flocks consisted of $72 \%$ adult females and $28 \%$ entire males of all villages (Table 3). Mortalities were relatively high at the early stages of age and gradually decreased with the progress of the newborn kids in age as shown in Table 3.

When farmers' observations about the reproductive behavior of goats were recorded, most farmers decided that the first estrus (74\%) and the first mating (64\%) of 
Table 1 Characteristics of sample farmers in rural areas of the Nile Delta in Egypt

\begin{tabular}{|c|c|c|c|c|c|c|c|c|c|c|c|c|}
\hline \multirow[t]{3}{*}{ Farmer particulars } & \multicolumn{10}{|c|}{ Villages } & \multirow{2}{*}{\multicolumn{2}{|c|}{$\begin{array}{l}\text { Total } \\
\text { farmers }\end{array}$}} \\
\hline & \multicolumn{2}{|c|}{ Shanway } & \multicolumn{2}{|c|}{ Kafr El Hema } & \multicolumn{2}{|c|}{ Sakyet Abu Sha'ra } & \multicolumn{2}{|c|}{ Samalay } & \multicolumn{2}{|c|}{ Kafr El Pharaonia } & & \\
\hline & $\mathrm{No.}^{*}$ & $\%$ & $\mathrm{No.}^{*}$ & $\%$ & $\mathrm{No.}^{*}$ & $\%$ & $\mathrm{No}^{*}$ & $\%$ & No.* $^{*}$ & $\%$ & $\mathrm{No.}^{*}$ & $\%$ \\
\hline \multicolumn{13}{|l|}{ Age } \\
\hline Not sure & 1 & 5 & 3 & 15 & 2 & 10 & 1 & 5 & 2 & 10 & 9 & 9 \\
\hline $20-30$ & 3 & 15 & 5 & 25 & 3 & 15 & 4 & 20 & 5 & 25 & 20 & 20 \\
\hline $31-40$ & 5 & 25 & 5 & 25 & 4 & 20 & 5 & 25 & 4 & 20 & 23 & 23 \\
\hline $41-50$ & 5 & 25 & 2 & 10 & 5 & 25 & 5 & 25 & 5 & 25 & 22 & 22 \\
\hline $51-60$ & 3 & 15 & 3 & 15 & 4 & 20 & 3 & 15 & 3 & 15 & 16 & 16 \\
\hline 61 and above & 3 & 15 & 2 & 10 & 2 & 10 & 2 & 10 & 1 & 5 & 10 & 10 \\
\hline \multicolumn{13}{|l|}{ Marital status } \\
\hline Married & 16 & 80 & 14 & 70 & 18 & 90 & 14 & 70 & 17 & 85 & 79 & 79 \\
\hline Single & 4 & 20 & 6 & 30 & 2 & 10 & 6 & 30 & 3 & 15 & 21 & 21 \\
\hline \multicolumn{13}{|l|}{ Gender } \\
\hline Male & 16 & 80 & 18 & 90 & 17 & 85 & 19 & 95 & 18 & 90 & 88 & 88 \\
\hline Female & 4 & 20 & 2 & 10 & 3 & 15 & 1 & 5 & 2 & 10 & 12 & 12 \\
\hline \multicolumn{13}{|l|}{ Education status } \\
\hline Illiterate & 3 & 15 & 4 & 20 & 2 & 10 & 3 & 15 & 2 & 10 & 14 & 14 \\
\hline Primary & 7 & 35 & 9 & 45 & 12 & 60 & 8 & 40 & 11 & 55 & 47 & 47 \\
\hline Secondary & 5 & 25 & 2 & 10 & 4 & 20 & 6 & 30 & 3 & 15 & 20 & 20 \\
\hline Graduated from university & 5 & 25 & 5 & 25 & 2 & 10 & 3 & 15 & 4 & 20 & 19 & 19 \\
\hline \multicolumn{13}{|l|}{ Land ownership } \\
\hline Lease & 8 & 40 & 10 & 50 & 6 & 30 & 11 & 55 & 5 & 25 & 40 & 40 \\
\hline Family & 6 & 30 & 4 & 20 & 4 & 20 & 6 & 30 & 8 & 40 & 28 & 28 \\
\hline Owner & 6 & 30 & 6 & 30 & 10 & 50 & 3 & 15 & 7 & 35 & 32 & 32 \\
\hline \multicolumn{13}{|l|}{ Source of income } \\
\hline Pension & 2 & 10 & 3 & 15 & 1 & 5 & 3 & 15 & 5 & 25 & 14 & 14 \\
\hline Work & 6 & 30 & 7 & 35 & 8 & 40 & 4 & 20 & 5 & 25 & 30 & 30 \\
\hline Sales & 2 & 10 & 1 & 5 & 1 & 5 & 2 & 10 & 1 & 5 & 7 & 7 \\
\hline Pension and sales & 1 & 5 & 1 & 5 & 2 & 10 & 3 & 15 & 2 & 10 & 9 & 9 \\
\hline Sales and work & 4 & 20 & 3 & 15 & 2 & 10 & 2 & 10 & 4 & 20 & 15 & 15 \\
\hline Pension and work & 3 & 15 & 2 & 10 & 4 & 20 & 3 & 15 & 1 & 5 & 13 & 13 \\
\hline Pension, work, and sales & 2 & 10 & 3 & 15 & 2 & 10 & 3 & 15 & 2 & 10 & 12 & 12 \\
\hline
\end{tabular}

does were relatively higher in the second half of the first year of age, specifically in the last quarter of the year. The kidding pattern of does showed distinct peaks throughout the year which the majority of the farmers (86\%) recorded that the kidding intervals less than or equal to 1 year and the age that ranges between 8 and 12 months were common in the area of study. While kidding intervals for more than one year were recorded for about $14 \%$ of farmers.Twin kids were the majority type of births (62\%), also does with multiple births were more popular and preferred (98\%) for farmers compared to single births (2\%). Across the villages under study, kids born as single were mentioned more frequently to have a generally high survival rate $(72 \%)$. However, twin kids also performed relatively well $(26 \%)$ as shown in Table 3.

\section{Importance of production categories of Baladi goats in rural areas of the Nile Delta in Egypt}

Table 4 gives the percentages for importance of production categories of goats. In relation to production categories, the number of kids born emerged as the most important categories for keeping goats in the opinion of all farmers (70\%). The amount of milk sold per year was the lowest important category in all villages under study $(6 \%)$. 
Table 2 Importance of livestock to farmers in rural areas of the Nile Delta in Egypt

\begin{tabular}{|c|c|c|c|c|c|c|c|}
\hline \multirow[t]{2}{*}{ Subcategory/Farmers } & \multirow{2}{*}{$\begin{array}{l}\text { Shanway } \\
\text { No.* }\end{array}$} & \multirow{2}{*}{$\begin{array}{l}\text { Kafr El Hema } \\
\text { No.* }\end{array}$} & \multirow{2}{*}{$\begin{array}{l}\text { Sakyet Abu Sha'ra } \\
\text { No.* }^{*}\end{array}$} & \multirow{2}{*}{$\begin{array}{l}\text { Samalay } \\
\text { No.* }^{*}\end{array}$} & \multirow{2}{*}{$\begin{array}{l}\text { Kafr El Pharaonia } \\
\text { No.* }\end{array}$} & \multirow[t]{2}{*}{ Mean \pm SE } & \multirow[t]{2}{*}{$\%$} \\
\hline & & & & & & & \\
\hline Crop farming & 15 & 18 & 12 & 16 & 18 & $15.80 \pm 1.113$ & 79 \\
\hline Livestock & 14 & 16 & 16 & 14 & 17 & $15.40 \pm 0.600$ & 77 \\
\hline Buffalo & 12 & 13 & 8 & 10 & 12 & $11.00 \pm 0.894$ & 55 \\
\hline Local cattle & 8 & 11 & 6 & 12 & 10 & $9.40 \pm 1.077$ & 47 \\
\hline Crossbred cattle & 8 & 7 & 4 & 6 & 6 & $6.20 \pm 0.663$ & 31 \\
\hline Sheep $^{a}$ & 12 & 15 & 14 & 12 & 15 & $13.60 \pm 0.678$ & 68 \\
\hline Goats $^{\text {b }}$ & 16 & 14 & 15 & 15 & 16 & $15.20 \pm 0.374$ & 76 \\
\hline Donkeys & 5 & 6 & 2 & 5 & 4 & $4.40 \pm 0.969$ & 22 \\
\hline Other (chickens, ducks, and rabbits) & 14 & 17 & 15 & 14 & 14 & $14.80 \pm 0.583$ & 74 \\
\hline
\end{tabular}

Multiple responses were possible, so the sum of percentages is not 100

aBaladi, Rahmani, and Ossimi

${ }^{\mathrm{b}}$ Baladi

Management procedures under different villages in rural areas of the Nile Delta in Egypt

Data recorded from this study showed that the common management systems in all villages were tethering (54\%). Most of farmers indicated that crop farming and livestock keeping as the main traditional system in their livelihoods (83\%), while the majority of the households (67\%) recorded suckling as the higher activity of kid-rearing system (Table 5). Only 50\% and 14\% regarded supplementation and identification systems, respectively. Performance recording activities were also reported. It was noted from the farmers' questionnaire that performance recording was not taken into consideration. Only $40 \%$ and $2 \%$ had access to veterinary and extension services, respectively. Their rate of interest in market access was low (17\%).

\section{Reasons for keeping goats in rural areas of the Nile Delta in Egypt}

Table 6 shows the percentages for the various reasons for keeping Baladi goats. The percentage was highest for cash and recorded $89 \%$ for all villages. Use of goats for social roles values such as dowry for marriage and gifts was the second with percentage (40\%) followed by values of raise to sell as needed (29\%) and exchange for cows (25\%). A few farmers in the study area considered goat meat production to basic needs as important (11\%). Only a few farmers kept goats for manure (4\%), skins (8\%), and milk (5\%).

\section{Constraints for goat farmers in rural areas of the Nile Delta in Egypt}

The majority of farmers (91\%) believed that lack of access to improved animals is the major constraint identified, while the majority of the farmers agreed that lack of extension services and disease control (81\%) are among their top three constraints. On the contrary, only $29 \%$ of the farmers cannot meet the veterinarian, Table 7 and Fig. 2.

The theft of goats is an important challenge for most farmers in the different villages under study, especially in the villages of Sakyet Abu Sha'ra (Fig. 2).

\section{Importance of goat diseases in rural areas of the Nile Delta in Egypt}

In this study, diseases were one of the major challenges faced by farmers that have negative effects on the

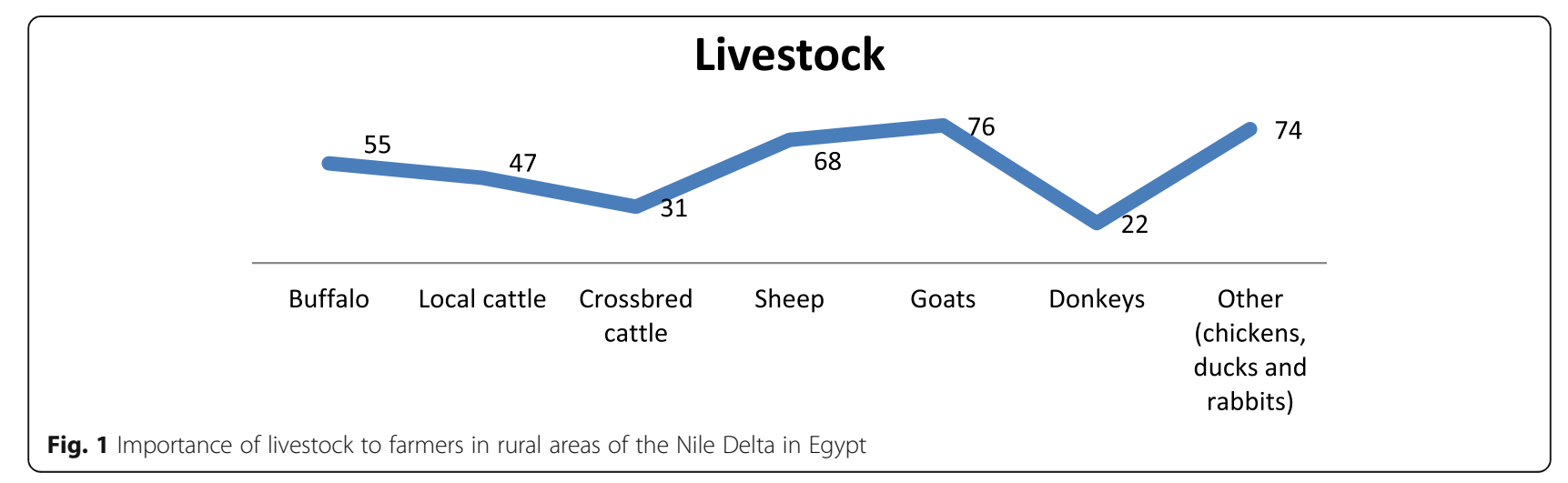


Table 3 Performance traits and characteristics of goats in rural areas of the Nile Delta in Egypt

\begin{tabular}{|c|c|c|c|c|c|c|c|c|c|c|c|c|c|}
\hline \multirow[t]{3}{*}{ Variables } & \multirow[t]{3}{*}{ Level/Range } & \multicolumn{10}{|c|}{ Villages } & \multirow[t]{3}{*}{ Mean \pm SE } & \multirow[t]{3}{*}{$\%$} \\
\hline & & \multicolumn{2}{|c|}{ Shanway } & \multicolumn{2}{|c|}{ Kafr El Hema } & \multicolumn{2}{|c|}{ Sakyet Abu Sha'ra } & \multicolumn{2}{|c|}{ Samalay } & \multicolumn{2}{|c|}{ Kafr El Pharaonia } & & \\
\hline & & No.* & $\%$ & No.* & $\%$ & No.* & $\%$ & No.* & $\%$ & No.* & $\%$ & & \\
\hline \multirow[t]{2}{*}{ Average flock size } & 1-3 head & 13 & 65 & 12 & 60 & 14 & 70 & 11 & 55 & 12 & 60 & $12.40 \pm 0.509$ & 62 \\
\hline & $>3$ head & 7 & 35 & 8 & 40 & 6 & 30 & 9 & 45 & 8 & 40 & $7.60 \pm 0.509$ & 38 \\
\hline \multirow[t]{2}{*}{ Flock structure } & Male & 7 & 35 & 5 & 25 & 6 & 30 & 4 & 20 & 6 & 30 & $5.60 \pm 0.509$ & 28 \\
\hline & Female & 13 & 65 & 15 & 75 & 14 & 70 & 16 & 80 & 14 & 70 & $14.40 \pm 0.509$ & 72 \\
\hline \multirow[t]{3}{*}{ Age at first estrus } & $<6$ months & 3 & 15 & 4 & 20 & 2 & 10 & 1 & 5 & 0 & 0 & $2.00 \pm 0.707$ & 10 \\
\hline & 6-12 months & 14 & 70 & 15 & 75 & 14 & 70 & 15 & 75 & 16 & 80 & $14.80 \pm 0.374$ & 74 \\
\hline & $>1$ year & 3 & 15 & 1 & 5 & 4 & 20 & 4 & 20 & 4 & 20 & $3.20 \pm 0.583$ & 16 \\
\hline \multirow[t]{2}{*}{ Average kidding interval } & 8-12 months & 14 & 70 & 18 & 90 & 16 & 80 & 19 & 95 & 19 & 95 & $17.20 \pm 0.969$ & 86 \\
\hline & $>1$ year & 6 & 30 & 2 & 10 & 4 & 20 & 1 & 5 & 1 & 5 & $2.80 \pm 0.969$ & 14 \\
\hline \multirow[t]{2}{*}{ Age at first mating of females } & $<1$ year & 12 & 60 & 11 & 55 & 13 & 65 & 16 & 80 & 12 & 60 & $12.80 \pm 0.860$ & 64 \\
\hline & $>1$ year & 8 & 40 & 9 & 45 & 7 & 35 & 4 & 20 & 8 & 40 & $7.20 \pm 0.860$ & 36 \\
\hline \multirow[t]{4}{*}{ Type of birth } & Single & 2 & 10 & 3 & 15 & 3 & 15 & 2 & 10 & 4 & 20 & $2.80 \pm 0.374$ & 14 \\
\hline & Twin & 10 & 50 & 13 & 65 & 16 & 80 & 12 & 60 & 11 & 55 & $12.40 \pm 1.029$ & 62 \\
\hline & Triplet & 6 & 30 & 2 & 10 & 1 & 5 & 4 & 20 & 4 & 20 & $3.40 \pm 0.871$ & 17 \\
\hline & Quartets & 2 & 10 & 2 & 10 & 0 & 0 & 1 & 5 & 1 & 5 & $1.20 \pm 0.374$ & 6 \\
\hline \multirow[t]{3}{*}{ Frequency of reproduction per year } & Not sure & 5 & 25 & 4 & 20 & 3 & 15 & 5 & 25 & 5 & 25 & $4.40 \pm 0.400$ & 22 \\
\hline & Once & 12 & 60 & 12 & 60 & 14 & 70 & 11 & 55 & 10 & 50 & $11.80 \pm 0.663$ & 59 \\
\hline & Twice & 3 & 25 & 4 & 20 & 3 & 15 & 4 & 20 & 5 & 25 & $3.80 \pm 0.374$ & 19 \\
\hline \multirow[t]{4}{*}{ Type of birth preferred } & Single & 0 & 0 & 0 & 0 & 0 & 0 & 1 & 5 & 1 & 5 & $0.40 \pm 0.244$ & 2 \\
\hline & Twin & 14 & 70 & 15 & 75 & 17 & 85 & 15 & 75 & 14 & 70 & $15.00 \pm 0.547$ & 75 \\
\hline & Triplet & 4 & 20 & 4 & 20 & 3 & 15 & 4 & 20 & 5 & 25 & $4.00 \pm 0.316$ & 20 \\
\hline & Quartets & 2 & 10 & 1 & 5 & 0 & 0 & 0 & 0 & 0 & 0 & $0.60 \pm 0.400$ & 3 \\
\hline \multirow[t]{4}{*}{ Survival rates } & Single & 13 & 65 & 14 & 70 & 16 & 80 & 13 & 65 & 15 & 75 & $14.20 \pm 0.583$ & 72 \\
\hline & Twin & 6 & 30 & 6 & 30 & 4 & 20 & 5 & 25 & 5 & 25 & $5.20 \pm 0.374$ & 26 \\
\hline & Triplet & 1 & 5 & 0 & 0 & 0 & 0 & 2 & 10 & 0 & 0 & $.60 \pm 0.400$ & 2 \\
\hline & Quartets & 0 & 0 & 0 & 0 & 0 & 0 & 0 & 0 & 0 & 0 & $.00 \pm 0.000$ & 0 \\
\hline \multirow[t]{3}{*}{ Mortality rates } & At birth & 11 & 55 & 17 & 85 & 12 & 60 & 13 & 65 & 12 & 60 & $13.00 \pm 1.048$ & 65 \\
\hline & $<6$ months & 6 & 30 & 3 & 15 & 4 & 20 & 6 & 30 & 5 & 25 & $4.80 \pm 0.583$ & 24 \\
\hline & 6-12 months & 3 & 15 & 0 & 0 & 4 & 20 & 1 & 5 & 3 & 15 & $2.20 \pm 0.734$ & 11 \\
\hline
\end{tabular}

Multiple responses were possible, so the sum of percentages is not 100 . Fertility $=$ number of does kidding per does mated. Kidding percentage $=$ number of kids born per breeding does mated

productivity of goats in the area under study. Parasites (both internal and external) and pneumonia emerged as important disease categories, but internal parasites were accorded high importance by all farmers (31\%). When we asked farmers about the most important diseases affecting goats, some of farmers said that internal parasites are the most deadly disease in the newly born kids. External parasites also came in the second class (30\%). The farmers considered pneumonia (25\%) to be highly important, whereas the farmers rated it second last, behind parasites diseases. Nutrition were rated lowest (14\%) of the four categories by all farmers (Table 8 and Fig. 4).
By comparing farmers in the villages surveyed, we observed that the external parasites are an important disease for most farmers in the village of Sakyet Abu Sha'ra, (Fig. 3).

\section{Marketing goat in rural areas of the Nile Delta in Egypt}

Butchers and traders are responsible for the marketing of goats in the different villages under study. Many farmers said they were selling their animals to traders who re-sold them in the trading markets that belong to Ashmoun town or other towns, sold them to butchers who owned small roadside butcher shops in towns or 
Table 4 Importance of product categories of goats in rural areas of the Nile Delta in Egypt

\begin{tabular}{lll}
\hline Subcategory & Mean \pm SE & $\%$ \\
\hline Number of kids born & $14.00 \pm 0.707$ & 70 \\
Number of goats sold per year & $12.80 \pm 0.583$ & 64 \\
Amount of milk sold per year & $1.20 \pm 0.200$ & 6 \\
Others (specify income source) & $9.00 \pm 0.707$ & 45 \\
\hline
\end{tabular}

Multiple responses were possible, so the sum of percentages is not 100

trading centers, and sold them to fellow farmers and other people in the neighborhood who purchased them for home consumption or to raise them. The price was subjectively based on the size and appearance of the animal, and it was settled after haggling with the buyer (Fig. 4).

Availability of buyers, consumer, sale price in market, and price spread in village were the factors farmers considered important when selling livestock (Fig. 5). The results showed that goats are the most common livestock of the rural farmers of the area of study (Fig. 1).

\section{General discussion}

General information of farmers in rural areas of the Nile

\section{Delta in Egypt}

The purpose of the present study was to provide a preferable understanding of goat production systems in rural areas of the Nile Delta in Egypt, by taking Menoufia as
Table 6 Reasons for keeping goats in rural areas of the Nile Delta in Egypt

\begin{tabular}{lll}
\hline Reason & Mean \pm SE & $\%$ \\
\hline Cash sale & $17.80 \pm 0.374$ & 89 \\
Meet basic needs & $2.20 \pm 0.374$ & 11 \\
Social roles & $8.00 \pm 0.547$ & 40 \\
Easy to raise and to sell as needed & $5.80 \pm 0.374$ & 29 \\
Manure & $.80 \pm 0.2000$ & 4 \\
Skins & $1.60 \pm 0.244$ & 8 \\
Milk for sale and home & $1.00 \pm 0.000$ & 5 \\
Exchange for cows & $5.00 \pm 0.707$ & 25 \\
Risk management & $4.80 \pm 0.374$ & 24 \\
\hline
\end{tabular}

Multiple responses were possible, so the sum of percentages is not 100

an example. This agrees with some findings of Laouadi et al. (2018) that reported that most of the respondents were married (86.8\%) in Laghouat area, Algeria. Most heads of households were male; only $12 \%$ of respondents were female. This disagrees with some findings that women constitute the majority of agricultural force in Nigeria (Pala 1980 and dachaba 1980). It however agrees with the findings of Iyiola-Tunji and Issa (2010) that reported low participation of female in adopted villages (AV) and non-adopted villages (NAV) in Nigeria. Adult women play the most important role in goat husbandry, although most of them declare that it is an adult's men responsibility. This agree with some findings of Kunene and Fossey (2006) of Northern Kwazulu Natal in South

Table 5 Goat management under different villages in rural areas of the Nile Delta in Egypt

\begin{tabular}{|c|c|c|c|c|c|c|c|c|c|c|c|c|c|}
\hline \multirow[t]{3}{*}{ Variables } & \multirow[t]{3}{*}{ Level/Range } & \multicolumn{10}{|c|}{ Villages } & \multirow{2}{*}{\multicolumn{2}{|c|}{$\begin{array}{l}\text { Mea } \\
(n=100)\end{array}$}} \\
\hline & & \multicolumn{2}{|c|}{ Shanway } & \multicolumn{2}{|c|}{ Kafr El Hema } & \multicolumn{2}{|c|}{ Sakyet Abu Sha'ra } & \multicolumn{2}{|c|}{ Samalay } & \multicolumn{2}{|c|}{ Kafr El Pharaonia } & & \\
\hline & & No.* & $\%$ & $\mathrm{No}^{*}$ & $\%$ & No.* & $\%$ & No.* & $\%$ & No.* & $\%$ & No.* & $\%$ \\
\hline \multirow[t]{4}{*}{ Management systems } & Tethering & 10 & 10 & 9 & 9 & 12 & 12 & 11 & 11 & 12 & 12 & 54 & 54 \\
\hline & Semi-intensive & 4 & 4 & 3 & 3 & 4 & 4 & 2 & 2 & 2 & 2 & 15 & 15 \\
\hline & Semi-extensive & 6 & 6 & 8 & 8 & 4 & 4 & 7 & 7 & 6 & 6 & 31 & 31 \\
\hline & Extensive & 0 & 0 & 0 & 0 & 0 & 0 & 0 & 0 & 0 & 0 & 0 & 0 \\
\hline \multirow[t]{3}{*}{ Traditional production systems } & Main occupation & 2 & 10 & 1 & 5 & 2 & 10 & 1 & 5 & 1 & 5 & 7 & 7 \\
\hline & Crop and livestock farming & 14 & 70 & 17 & 85 & 16 & 80 & 19 & 95 & 17 & 85 & 83 & 83 \\
\hline & Small-scale trade & 4 & 20 & 2 & 10 & 2 & 10 & 0 & 0 & 2 & 10 & 10 & 10 \\
\hline \multirow[t]{2}{*}{ Kid-rearing system } & Hand-fed & 8 & 40 & 6 & 30 & 6 & 30 & 8 & 40 & 5 & 25 & 33 & 33 \\
\hline & Suckling & 12 & 60 & 14 & 70 & 14 & 70 & 12 & 60 & 15 & 75 & 67 & 67 \\
\hline Identification systems $^{a}$ & & 4 & 20 & 3 & 15 & 2 & 10 & 3 & 15 & 2 & 10 & 14 & 14 \\
\hline Performance recording ${ }^{a}$ & & 1 & 5 & 0 & 0 & 0 & 0 & 0 & 0 & 1 & 5 & 2 & 2 \\
\hline Supplementation ${ }^{a}$ & & 10 & 50 & 8 & 40 & 11 & 55 & 9 & 45 & 12 & 60 & 50 & 50 \\
\hline Request for veterinary services ${ }^{a}$ & & 8 & 40 & 9 & 45 & 4 & 20 & 10 & 50 & 9 & 45 & 40 & 40 \\
\hline Request for extension services ${ }^{a}$ & & 0 & 0 & 1 & 5 & 0 & 0 & 1 & 5 & 0 & 0 & 2 & 2 \\
\hline Access to agricultural markets ${ }^{a}$ & & 5 & 25 & 4 & 20 & 3 & 15 & 1 & 5 & 4 & 20 & 17 & 17 \\
\hline
\end{tabular}

${ }^{a}$ Multiple responses were possible, so the sum of percentages is not 100 
Table $\mathbf{7}$ Constraints for goat farmers in rural areas of the Nile Delta in Egypt

\begin{tabular}{lll}
\hline Problems & Mean \pm SE & $\%$ \\
\hline Lack of access to improved animals & $18.20 \pm 0.374$ & 91 \\
Low fertility in animals & $10.20 \pm 0.800$ & 41 \\
Feeding problems & $5.20 \pm 0.489$ & 26 \\
Lack of extension services & $16.40 \pm 0.678$ & 82 \\
Lack of veterinary services & $5.80 \pm 0.663$ & 29 \\
Livestock disease & $12.00 \pm 0.836$ & 60 \\
Disease control & $16.20 \pm 0.583$ & 81 \\
Kid losses & $8.60 \pm 1.208$ & 43 \\
Abortion & $4.00 \pm 0.447$ & 20 \\
Livestock theft & $11.60 \pm 0.509$ & 58 \\
Fencing & $12.00 \pm 0.707$ & 60
\end{tabular}

Multiple responses were possible, so the sum of percentages is not 100

Africa. The fact that livestock production activities are still carried out by able-bodied farmers is supported in this study. The low literacy level in the study area consider strength in enhancing goat breeding strategies because scientifically qualified communities are more likely to adopt and practice new technologies, which may enhance the rural development. Most of the participants from the village of Sakyet Abu Sha'ra farm work in the field of hand-made carpets, where their factories are in their houses, therefore they do not leave the village for any reason, which may lead to an increase their attention to buy land compared to other villages.
Importance of livestock to farmers in rural areas of the Nile delta in Egypt

The combination of livestock owned in these rural areas was similar to other investigations conducted in other rural areas of southern Africa; Swaziland (Sibisi 1979) and Transkei (Bembridge 1984).

\section{Productive and reproductive traits of Baladi goats in rural areas of the Nile delta in Egypt}

The observations by farmers showed that the first kids at the age of 10 months corroborate earlier findings elsewhere in Zimbabwe (Kusina and Kusina 2002). Findings from this study are in contrast with that of Kusina and Kusina (2002). They reported higher survivability of pre-weaning kids. This might be partly attributed to the very low pre-weaning kid mortality. Also, these results agree with several research findings in Zimbabwe and other southern African countries where pre-weaning kid mortality has been reported to vary from 20 to 65\% (CARD 1992; Kusina et al. 1999). Also, Abd-Allah et al. (2015) recorded that the pre-weaning kids had the highest mortality rate compared to other ages.

\section{Importance of production categories of Baladi goats in rural areas of the Nile delta in Egypt}

Generally speaking, majority of farmers agrees that goat milk is not sold; however, there are a few proportions of women who reported that goat milk may be used in their babies suckling but men are not aware of it. Goats were reported to be used for similar functions (consumption, sale and cultural use).

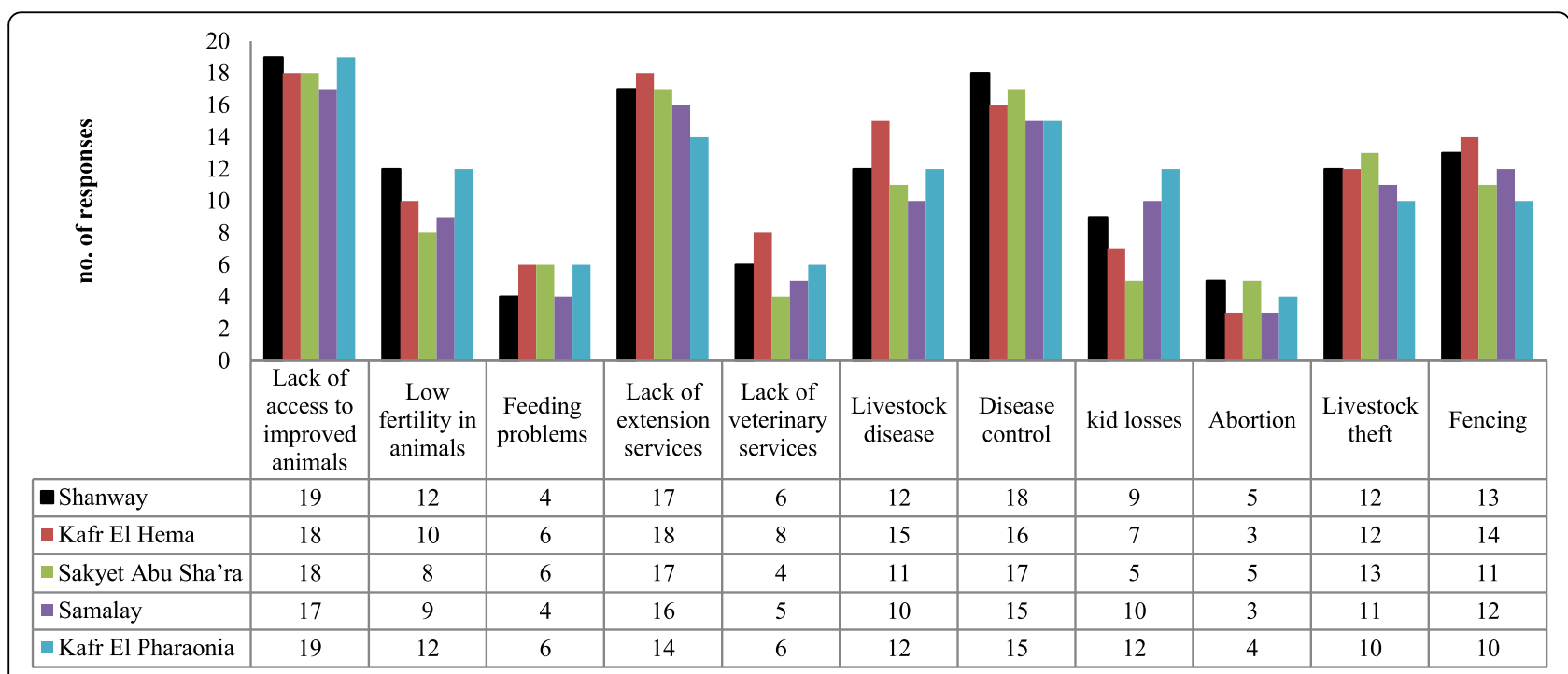

Fig. 2 Constraints for goat farmers in rural areas of the Nile Delta in Egypt 
Table $\mathbf{8}$ Importance of goat diseases in rural areas of the Nile Delta in Egypt

\begin{tabular}{lll}
\hline Subcategory & Mean \pm Std. error & \\
\cline { 2 - 3 } & No. ${ }^{*}$ & 31 \\
\hline Parasites: internal & $6.20 \pm 0.374$ & 30 \\
Parasites: external & $6.00 \pm 0.316$ & 14 \\
Nutrition & $2.80 \pm 0.200$ & 25 \\
\hline Pneumonia & $5.00 \pm 0.447$ & \\
\hline
\end{tabular}

Management procedures under different villages in rural areas of the Nile delta in Egypt

From the above, the traditional system can be characterized as mixed crop and livestock production systems and this is the common system in most rural areas in the Delta governorates. This is a common practice to stop goats from straying into crop gardens to destroy crops, in places where land is limited and there is mixed crop and livestock production systems. Meanwhile, the management systems observed in this survey are similar to the systems practised by other smallholder farmers in crop-livestock farming systems in a semi-arid smallholder farming area situated in the north of Zimbabwe Kusina and Kusina (2002). The study also found that most of the farmers in the villages surveyed did not give positive indicators of access rates for extension and veterinary services.

\section{Reasons for keeping goats in rural areas of the Nile delta in Egypt}

The percentages for the various reasons for keeping Baladi goats was highest for cash and followed by the use of goats for social roles values and exchange for cows. These results was supported by those of Moorosi (1999) who reported that livestock is the major source of income for South
African small-scale farmers. Also, he reported that $79 \%$ of the farmers sold their goats when there was a need for cash like school fees. To understand why farmers would prefer goats on the other animals, we asked farmers what their reasons were for keeping goats. For the purpose of this study, income was defined as money for basic needs, which means that the farmers need the money from the sale of their animals, for example, to help buy electrical equipment to prepare their daughters for a marriage or to meet an urgent and basic need such as preparing a family member for marriage or immediate payment of school fees.

Also, Muslims slaughter their goats during the Eid alAdha season as offerings to God. These results seem to suggest that upgraded local goats are reared mostly for the money and are also important for other uses. The characteristic common to local goats which the farmers appreciated was that they were easy to raise, requiring few inputs. Most of the goats reared were Baladi. The local goats are known to be well suited in rural areas for poor households as they are stable on production even with minimal inputs. Generally, rural farmers do not sell their goats at maturity; they raise them to sell when they have a serious financial need. Farmers in the study area do not regularly slaughter their goats for food. When we asked them what is the most important animal food source, the most common responses were milk of buffalo and cow, eggs, and fish.

\section{Constraints for goat farmers in rural areas of the Nile delta in Egypt}

By asking farmers about genetic improvement techniques and their applicability to their animals, such as artificial insemination and crossbreeding with improved breeds, some of the farmers answered that they have no idea what they are hearing but are willing to adopt such techniques if possible. On the other hand, some of the farmers have

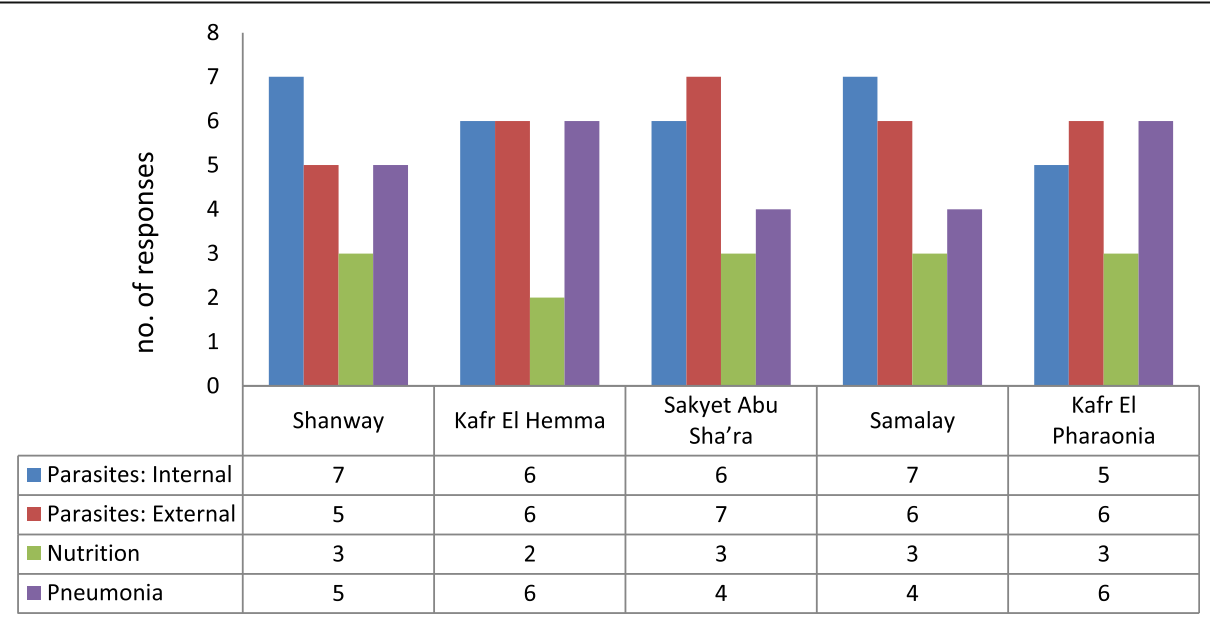

Fig. 3 Importance of goat diseases in rural areas of the Nile Delta in Egypt 


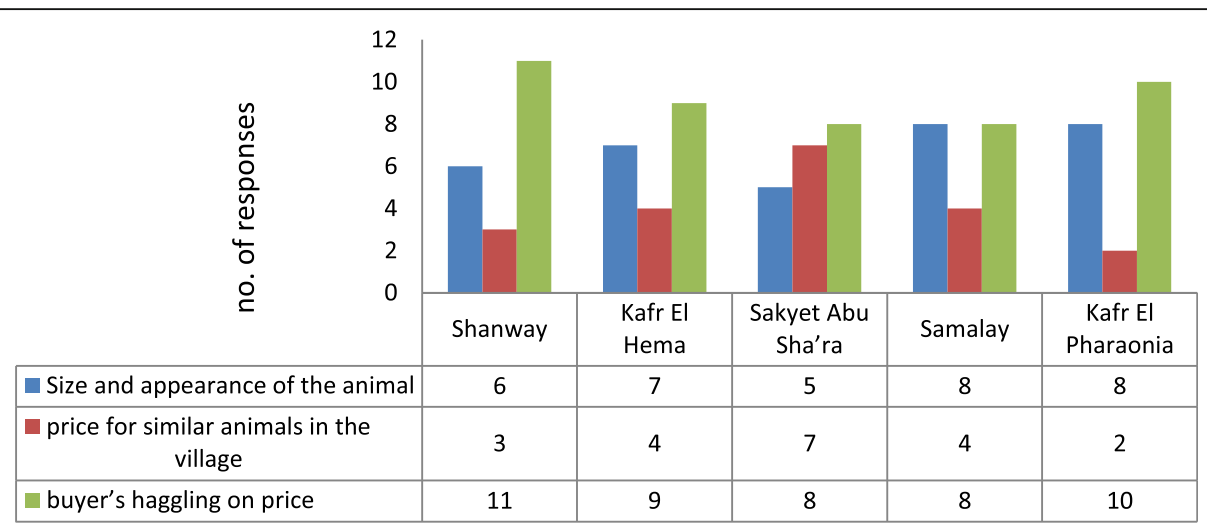

Fig. 4 Factors considered when determining the price to sell animals

indicated that they are looking to get the improved goats, especially the Boer goats, because of its good reputation. The farmers also need to be taught new breeding strategies in order to be able to deal with improved breeds of goats in case government organizations take account the development of this vital sector. Participating farmers reported that there was no encouragement from government organizations to rear high-producing improved breeds which often require more inputs.

Most of the interviewed farmers responded that they got information on the best medical cares for goats, feeding, diseases, preventive care, and general information from the veterinarian. In general, the farmers interviewed provided a smaller variation in the benefits of their meetings with the veterinarian, which is logical since they have more experience and prefer traditional treatment for their sick animals. Most of the rural farmers periodically experience loss of their goats because of factors like disease and theft. Probably that is why Baladi goats are common in rural areas. Goats are somewhat like pets in rural Egypt; they sometimes ride in public transportation busses or trains and are welcomed in the owner's houses. The theft of goats is an important challenge for most farmers in the different villages under study, especially in the villages of Sakyet Abu Sha'ra and Kafr El Hema. Some farmers mentioned that theft of goats increases during the winter season and that the livestock thieves cross the eastern side of Damietta branch of the Nile river by sailboats. Most farmers also pointed out that there is no role for the police stations or police units deployed in the villages in retrieving these animals or even eliminating this phenomenon. The problems associated with raising goats without a fencing structure may be due to the poverty of farmers who cannot afford fencing to shun them or maybe due to their lower ownership from goats, just one or two head per farmer $(62 \%$ of the farmers own three goats or fewer). It was reported that goats cause problems when left to roam around, especially in the winter seasons because of mud. Some of the tethered goats break loose, take off the stake, and cut the rope, especially if it is made from plant fiber and thus destroys crops. The rooting is also a problem as they can uproot crops, destroy the farmer's house, especially the mud and wattle houses, Fig. 6 . Similar practices have been reported elsewhere in Africa, for

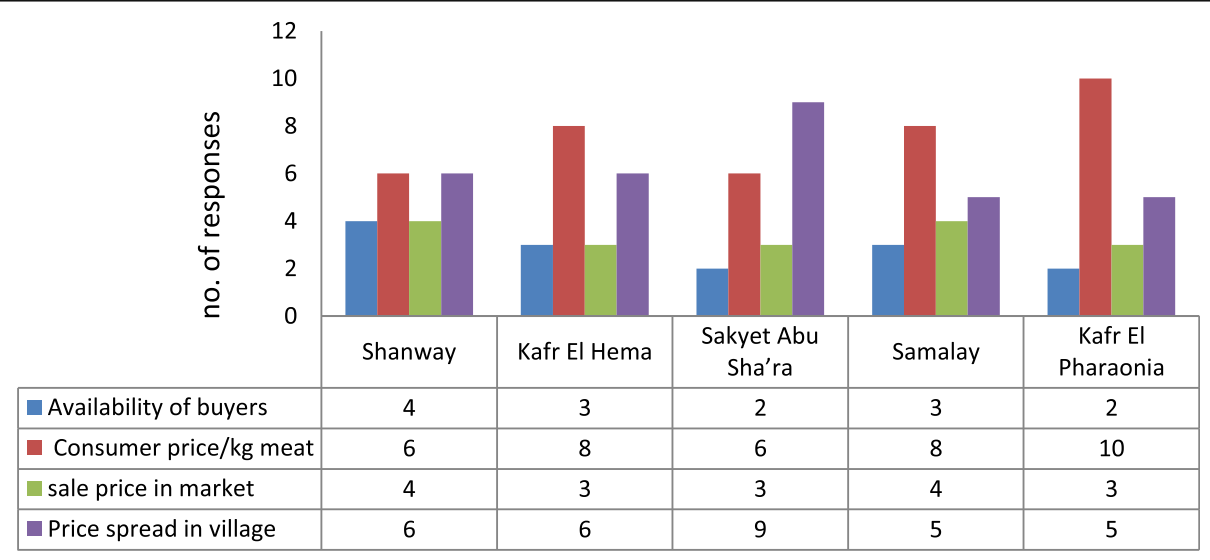

Fig. 5 Factors considered important in selling goats 

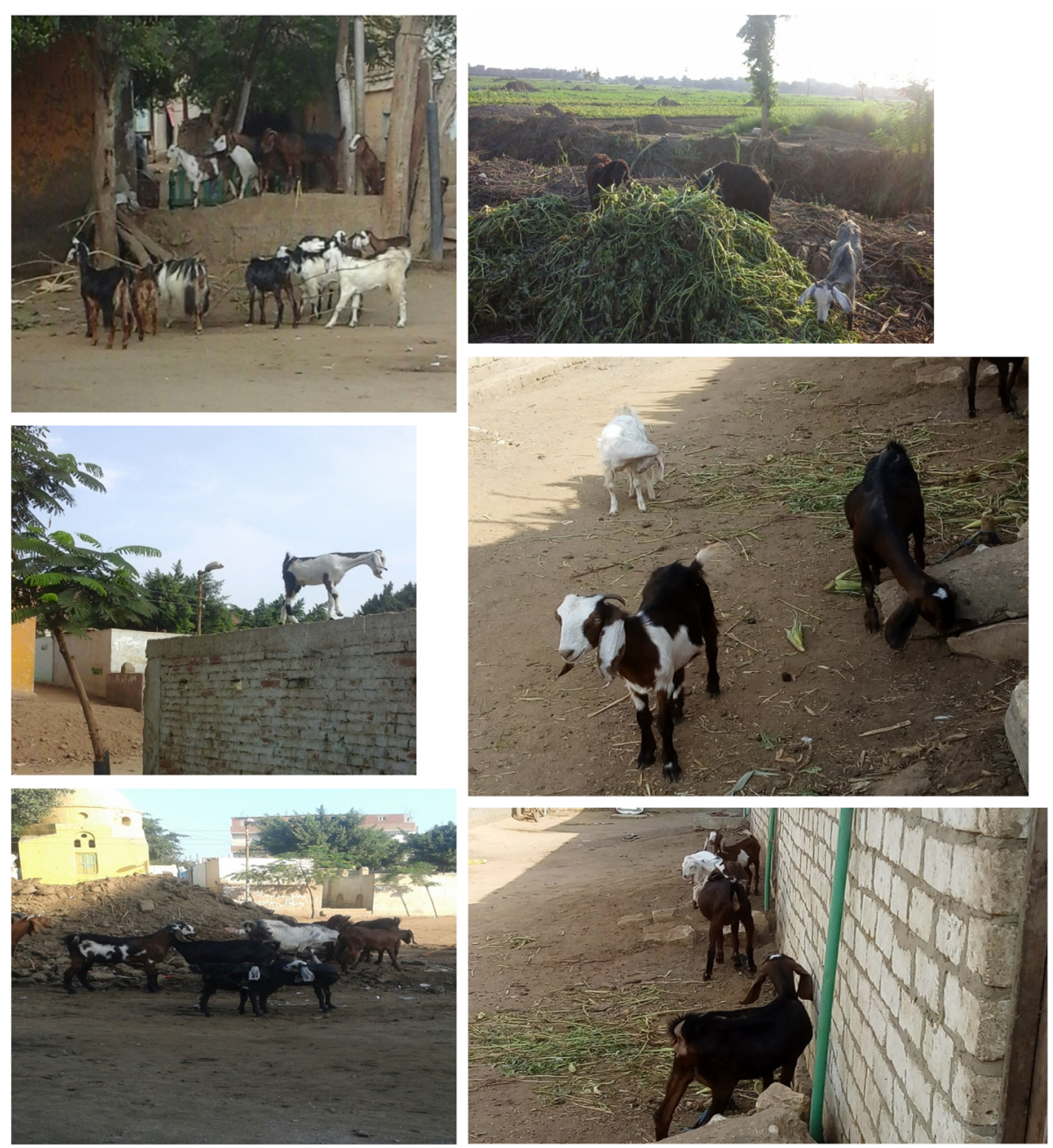

Fig. 6 Baladi goats outside their night housing at some villages under study

example, in Tanzania (Kakengi et al. 2000) and Nigeria (Ogebe et al. 2000).

\section{Importance of goat diseases in rural areas of the Nile delta in Egypt}

The major diseases in this area are internal and external parasites. This agrees with some reports which benefit that major diseases were internal and external parasites and foot and mouth disease (Waiswa et al. 2006; Kasambula et al. 2012). Although the questions covered goats specially, the categories of disease are all applicable to other ruminants, and all farmers agreed independently upon four diseases of goats as the most important. Therefore, the results of other diseases of goats mentioned by a minority of farmers are not presented. We asked them about the source of drugs which they use; they replied that they go to some animal health technicians to diagnose and give the necessary treatment, while some of them said that they prefer to go to the veterinary unit with their sick animals to be treated by a veterinarian, but most of them preferred the first choice.

\section{Marketing goat in rural areas of the Nile delta in Egypt}

Usually, farmers sell their livestock because of an urgent financial need; therefore, they are prone to exploitation by buyers and often get low prices for their animals (Dolan 2005; Turner 2005). Other problems are that buyers are not available at some time when farmers need to sell their animals. It was easier to sell a few animals; it was a problem to find buyers who would buy in bulk. Goats are not sold through any formal market channel and goat meat is not found in any butchery or shelves of the villages' supermarkets.

\section{Conclusions}

This survey has proved the need to describe each traditional rural production system prior to any intervention, as the general comprehension that these production 
systems are similar is incorrect. Also, special attention should be paid to small ruminants, especially goats. As such, the traditional production system along with feed shortage requires the improvement of husbandry practices. Whereas and despite all constraints and challenges currently facing the goat production system, there are still encouraging opportunities and potentials to boost production of the goat. Based on the results, it can be concluded that the improvement of goats' husbandry in rural areas requires adequate understandings of the production systems and its operation. Reflecting this on the level of food security in rural areas of The Nile Delta in Egypt.

\section{Abbreviations}

ARC: Agricultural Research Center; ARDC: Agricultural Research and Development Council; ARE: Arab Republic of Egypt; AV: Adopted villages; CAPMAS: Central Agency for Public Mobilization and Statistics; CARD: Coordinated agricultural research development; NAV: Non-adopted villages; SPSS: Statistical Package for Social Sciences

\section{Acknowledgements}

The authors would like to acknowledge the participants (farmers, herders, butchers in addition to veterinary technicians, and agricultural extension workers) in the study area to help us and willingness to participate in this study.

\section{Funding}

Some authors were responsible for funding this research. While most of the costs were covered by the first author.

\section{Availability of data and materials}

The data were obtained directly from the participants in addition to the secondary data obtained by the communication with Employees of General Directorate of Agriculture of Menoufia (GDA), the Directorate of Veterinary Medicine of Menoufia (DVM), and Ashmoun City Council of Menoufia (ACC) The data were obtained directly from the participants in addition to the secondary data obtained by the communication with Employees of Genera Directorate of Agriculture of Menoufia (GDA), the Directorate of Veterinary Medicine of Menoufia (DVM) and Ashmoun City Council of Menoufia (ACC) on the basis of a letter from the Vice President National Research Centre for Research and International Relations to the competent authorities to facilitate the task of the first author.

\section{Authors' contributions}

A-AS. performed the survey study and wrote the manuscript. MIM designed the manuscript. MMS and FMS reviewed the manuscript. HHA-ER participated in design the questionnaire form. All authors read and approved the final manuscript.

\section{Ethics approval}

Not applicable.

\section{Consent for publication}

Not applicable.

\section{Competing interests}

The authors declare that they have no competing interests.

\section{Publisher's Note}

Springer Nature remains neutral with regard to jurisdictional claims in published maps and institutional affiliations.
Received: 5 April 2019 Accepted: 21 June 2019

Published online: 19 July 2019

\section{References}

Abd-Allah, S. (2014). Application of some crossbreeding and feeding programs to improve the productive performance in Baladi goats. Unpublished Ph.D. Thesis, Fac. of Agric., Al-Azhar Univ. http://thesis.mandumah.com/Record/ 277060

Abd-Allah S, Mohamed Ml, Abd-Elrahman HH, EL-Kady RI (2016) Assessment of some productive performance of Boer goats and their crosses with Egyptian Baladi goats. Int J ChemTech Res 9(12):259-265 ISSN: 0974-4290

Abd-Allah S, Salama R, Mohamed MI, Mabrouk M, El-Kady RI, Kadry Al, Ahmed SM (2015) A comparative study on reproductive and productive performance of Boer and Baladi goats raised under similar environmental conditions in Egypt. Int J ChemTech Res 8(9):225-236 (ISSN: 0974-4290)

Bembridge TJ (1984) A systems approach study of agricultural development problems in Transkei. PhD Thesis, University of Stellenbosch, South Africa

CAPMAS (2018) Central Agency for Public Mobilization and Statistics, Egypt https://www.capmas.gov.eg/Pages/StaticPages.aspx?page_id=5035

CARD (1992) Co-ordinated agricultural research development. Small ruminants in Zimbabwe. Discussion paper, Republic of Zimbabwe, p 57. https://docplayer. net/29664580-A-survey-on-goat-production-in-a-semi-arid-smallholderfarming-area-situatedin-the-north-of-Zimbabwe.html

Dolan CS (2005) Household composition and rural livelihoods in Uganda. In: Ellis F, Freeman HA (eds) Rural livelihoods and poverty reduction policies. Routledge, New York, pp 15-234

Idachaba, F. S. (1980). Concepts and Strategies of Integrated Rural Development: Lessons from Nigeria. Food Policy Technical Research Paper No. 1, Department of Agricultural Economics, University of Ibadan, Nigeria. 88 P.

Iyiola-Tunji AO, Issa FO (2010) Small ruminant production characteristics by rural farm-families in naerls-adopted and non-adopted villages in north-western Nigeria. Cont J Anim Vet Res 2:18-24 https://www.researchgate.net/ publication/283426630

Kakengi AMV, Mtenga LA, Kimambo AE, Mgheni DM (2000) Performance of two strains of tethered and supplemented small East African goats. In: Proceedings of the 27th scientific conference UCLAS-Dar es Salaam, Tanzania, vol 27, pp 107-125

Kasambula L, Belsham JG, Siegismund HR, Muwanika VB, Ademun-Okurut AR, Masembe C (2012) Serotype identification and VPI coding sequence analysis of foot-and-mouth disease viruses from outbreaks in eastern and northern Uganda in 2008/9. Transbound Emerg Dis 59:323-330. https:// doi.org/10.1111/j.1865-1682.2011.01276

Kunene NW, Fossey A. (2006). A survey on livestock production in some traditional areas at Northern KwaZulu-Natal in South Africa. Livest Res Rural Dev. 18(8). http://www.cipav.org.co//rrd//rrd18/8/kune18113.htm.

Kusina NT, Kahiya C, Mukaratirwa S, Chikura S, Sibanda S (1999) Seasonal pattern in parasitic infection in Zimbabwean communal land goats. Zimb Vet J 30:41-54

Kusina NT, Kusina JF (2002) A survey on goat production in a semi-arid smallholder farming area situated in the north of Zimbabwe. JASSA 8(1):16-24

Laouadi M, Tennah S, Kafidi N, Antoine-Moussiaux N, Moula N (2018) A basic characterization of small-holders' goat production systems in Laghouat area, Algeria. Pastoralism 8:24

Moorosi LE (1999) Characterization of small-scale cattle farming in Botshabelo and Thaba Nchu districts of the Free State. M Sc Thesis. University of the Orange Free State, South Africa

Ogebe PO, Ogwu AO, Mustafa BS, McDowell LR (2000) Effect of tethering feeding system on the performance of West Africa dwarf goats. Livest Res Rural Dev 12:1-7

Pala AO (1980) The Joluo Equation, land reform, lower status for women. FAO Review on Agriculture and Development, p 69

Randolph TF, Schelling E, Grace D, Nicholson CF, Leroy JL, Cole DC, Demment MW, Omore A, Zinsstag J, Ruel M (2007) Role of livestock in human nutrition and health for poverty reduction in developing countries. J Anim Sci. 85:2788-2800. https://academic.oup.com/jas/article/ 85/11/2788/4778920

Safeopedia, 2019. Definition-what does rural area mean? https://www. safeopedia.com/definition/2958/rural-area 
Sibisi H (1979) Cattle ownership and control sociological observations on some aspects of rural development in Swaziland. Paper no. 1. Minisrty of Agriculture and Cooperatives, Mbabane

Sibisi H (1981) Keen farmers on Swazi nation land: economic and analysis section. Ministry of Agriculture and Cooperatives, Mbabane

SPSS (2008) Statistical package for social sciences for window, version 17.0. SPSS Inc.USA, Chicago

Turner RL (2005). Livestock, Liberalization and Democracy: Constraints and Opportunities for Rural Livestock Producers in a Reforming Uganda. Pro-poor Livestock Policy Initiative FAO. Google Scholar

Waiswa C, Picozzi K, Katunguka-Rwakishaya E, Olaho-Mukani W, Musoke AR, Welburn SC (2006) Glossina fuscipes in the trypanosomiasis endemic area of south eastern Uganda. Apparent density, trypanosome infection rates and host feeding preferences. Acta Trop 99:23-20. https://doi.org/10.1016/j. actatropica.2006.06.005

Submit your manuscript to a SpringerOpen ${ }^{\mathcal{O}}$ journal and benefit from:

- Convenient online submission

Rigorous peer review

- Open access: articles freely available online

- High visibility within the field

- Retaining the copyright to your article

Submit your next manuscript at $\boldsymbol{\nabla}$ springeropen.com 